\title{
THE ELECTROPHYSIOLOGICAL STUDY ON THE DIRECT POTENTIALS OF THE COCHLEAR DUCT
}

IKUO ISE, M. D.

\author{
Department of Otolaryngology, Tohoku Uuiversity School of Medicine
}

(Director: K. Kawamoto M. D.)

\begin{abstract}
To study the dependence of direct potentials - Endocochlear DC potential (EP) and Intracellular negative potential (INP) - on endocochlar energy various conditions were applied systemically to each energy production and utilization system.

As the results, it revealed that in EP consists of two elements; one is positive element $(+\mathrm{EP})$ that needs high energy for the generation, the other is negative element $(-\mathrm{EP})$ that scarcely needs energy. It is considered that the generation of INP needs also energy produced in cochlea, but not so much amount as positive EP.
\end{abstract}

$\underline{\mathrm{A} 82-0382-23020}$

\section{各種条件下に括ける螖牛内直流電位汇関する実験的研究}

東北大学医学部耳算咽喉科学教室（主任：河本和友教授）

等 郁 夫

緒豆

内耳の蝸牛電位のうち, 直流電位は1952年 Bèkèsy ${ }^{1)}$ Kよって発見された内リンパ酉流電位とラ七ン器負電估 (Intracellular negative potential 以下 INP と略す) である。前者は後飞半規管のそれに比較し，かなり差異が ある事加ら蜳牛值流笔位 (Endocochlear DC potential: 以下 EP と略与) と訂正された22。この EP の発生部 位は的成の血管条であり ${ }^{32}$ ，血行依存度が高く酸素久义 で容易に低下し負の電位（以下，-E P と略す）となる事 が知られているすか．またこの電位の大きさについても 基底回転加占第 4 回転亦で+80〜90 $\mathrm{mV}$ とはぼ一定でで ある事 ${ }^{408}$ が媇められている。しかしながら，EPの発 生機棰並びに存在意義等については未解明な点も多い。 Davis が提唱した「これらの螖牛直流電位が蛁牛マイタ

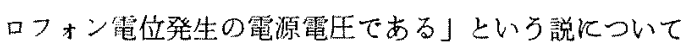

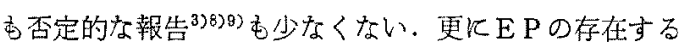

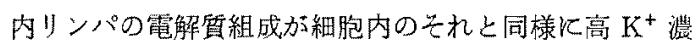
度である(0)ところから E Pは $\mathrm{K}^{+}$敒意義が求められた。

Kuijpers は「血管条に (electrogenic pump) が存社 し，この装置が血管条から内りンパ氏 $\mathrm{K}^{+}$分泌する機辚
でり、この装置の作働時に正のEP（以下+EPと略 す) が出現し，一EPは内外リンパのイオン濃度差（特 飞 $\mathrm{K}^{+}$) と雨者を境している膜の透過性儿由来する搪散

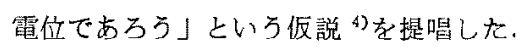

内リンパの高 $\mathrm{K}^{+}$浱度の存在がラセン器感賞有毛細胞 の高感度維持に必須なる条件の一つである事は周知の事 実であり，Kuijpers の仮説が事実とすれば種々の型の

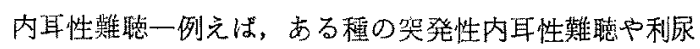

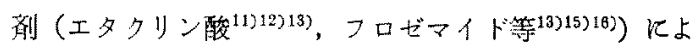
万内耳性難聴等一の病態生理を解明するためKE P の変 化の解析が重要な手掛かりとなるう。

他万, ラセン器真笔位即ち INP は感觉有毛細胞を有 するのみならず内外りンパを境するラセン器構成細胞内 静止電位である事が細胞マーキングの成績並びに電極先

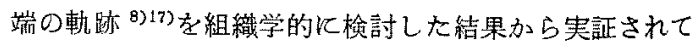
いる。本実験ではEPの発生機榡にエネルギー源が関与 しているか否かを検萦すると共に INP と E P との相互 関係を詳細観祭し，これらの結果汃与EPの発生機構 の解明学試みた。な就，EP発生機構にエネルギー源関 与の有然に関する研觉方法としては内耳螖牛のエネルギ 


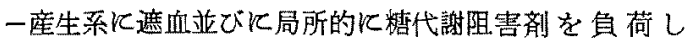
た. 遮血は上行大勤脈切断で行ない，糖代謝阻害剤とし ては従来，生化学的研究領域で使用されている筑国内の 用量でモノヨード酶酸 (Monoiodoacetic acid ${ }^{18) 19>20) 21}$, 以下 MIAA と略す), P-Hydroxymercuri benzoic acid 22)23) (以下 $\mathrm{p}-\mathrm{HMB}$ と略す), Mersalyl acid 22223)24)(以 下MAと略す）を用いた，な拓，これら糖代謝阻害㓮の 局所的投与法としては外リンパを介しての灌流目荷法を 行なったが，実験動物として使用したモルモットの外リ ンパの half perilymphatic volume $(8 \mu l)$ が約10分毎 飞交換されるという報告 ${ }^{25)}$ と，内外りンパへの灌流負荷 時に起こる圧効果等の混入を防止出来る萿流量として $6.8 \mu \mathrm{l} / \mathrm{min}$ で負荷を行なった.

\section{実酸動物並びに方法}

\section{1）実験動物並びに手術方法}

体重 250-350g，プシイエル耳乔反射正常なる有色も ルモット 97 匹を使用した、ネンブタールの腹腔内注射 $(28 \mathrm{mg} / \mathrm{kg})$ 飞よる麻酔ののち，背卧位で頭部を特殊固 定器の支持器に固定した．更に，フラキシデールを静脈 内注射 $(2 \mathrm{mg} / \mathrm{kg})$ 乙て筋弛綏させ，動物の呼吸は気管 切開部の捕入管を介して人工呼吸器により管理した，そ の後，下顎方向から中耳骨胞を大きく削開し蝸牛を露出 した。な拉，遮血実験に使用された動物は上行大動脈が 充分任確認出来るまで左第 2 第 3 助骨を切除した. 実 験中の動物の体温は䄪 $37^{\circ} \mathrm{C}$ (直腸内温度)飞保ち，同 時仙心電図も記録観祭した。

2）導出使用された電極之部録方法.

$\mathrm{EP}$ 並びに INP の導出電極怯 $150 \mathrm{mEq} / l$ のCL 溶 液を充㙋した先端 $2 \sim 3 \mu \mathrm{m}$, 抵抗 10 20M $\Omega$ のガラス 電極汇銀一塩化銀線を連結したものを使用した．無関電 極はリンゲル液を浸した線球に銀一塩化銀線を巻きつ け，この綿球を䅡筋上代置いた，また，リンゲル轱内で

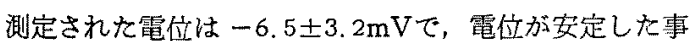
を確認してから本実験で使用した。導出された電位山直 線增幅器 (Grass P-18, 入力抵抗 $10^{12} \Omega$ ) て增幅し, 電 王計（Western 1240）並びとペンレコーダーを用いて観 察記録した（図 1).

3）電極の刺入経路

EP と INP と同一電極て道出する目的と, 更飞内

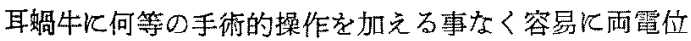

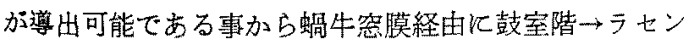
器 (INP 導出) $\rightarrow$ 蝸牛管（EP 導出）の㮌に電極を刺入

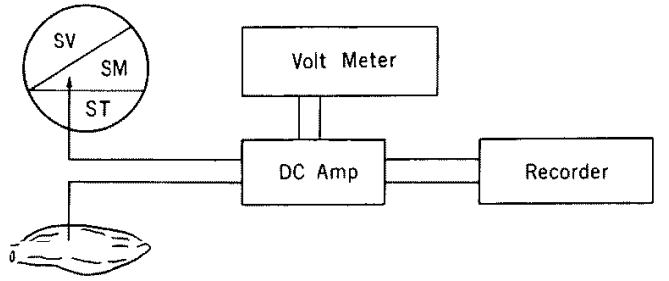

図 1 EP, INP 導出法

した，他力，蝸牛空経由飞導出された $\mathrm{EP}$ と此較するた め，第 2 回転の蝸牛側壁（経血管条）経由蛤牛管内炕 雪極を刺入し EP を導出した。

4）蝓牛への負荷方法

A 対照実験

内耳蜩牛儿真街老加えないで，EPとINP との㥵対 的関保を経時的に観察記録した。

\section{B 遮血実験}

あらかじめ簬出しておいた上行大動脈を INP 並びれ

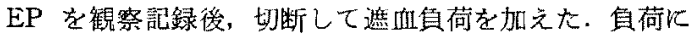
よる両電位の变化委経時的に観祭記録した.

\section{C 外リンパ灌流法による薬郕脃荷}

内耳蝸牛の基底回転で蝸牛空膜近在部に灌流入口を， 前庭空近在壁化灌流山口をそれぞれ作成し，灌流器 （Harvard \#940）飞連結した薬剂溶液を港流投与し負荷 を加えた. 薬凨の稀釈溶解液として近年広く人工外リン パとして使用されている Fex 氏液（表1）を用いた。 薬剂の灌流投与量住 $6.8 \mu \mathrm{l} / \mathrm{min}$ である。 また，灌流液

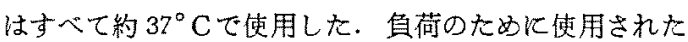
楽剂は糖代謝阻害郕で 0,1〜1 m M浱度の MIAA，pHMB，MA一いづれも「Sigma」一である.

表 1 Fex 氏 液

\begin{tabular}{ll}
\hline $\mathrm{NaCL}$ & $7,306(\mathrm{~g})$ \\
$\mathrm{NaHCO}$ & 2,100 \\
$\mathrm{~K} \mathrm{CL}$ & 0.261 \\
$\mathrm{CaCL}_{2}$ & 0.144 \\
$\mathrm{MgCL}_{2}$ & 0.109 \\
$\mathrm{NaH}_{2} \mathrm{PO}_{4} \cdot \mathrm{H}_{2} \mathrm{O}$ & 0.070 \\
Urea & 0.130 \\
Glucose & 0.610 \\
\hline
\end{tabular}

上記薬量蒸留水 $1,000 \mathrm{~m} l$ 飞溶解 $(\mathrm{pH} \fallingdotseq 8.2)$ 儿, $\mathrm{O}_{2}-\mathrm{CO}_{2}$ ガス $(95 \%-5 \%)$ で $\mathrm{pH} \doteqdot 7.3 \sim 7.4 \mathrm{~K}$ なる迄 Bubbling. 


\section{実酫結果}

1）対照実験

螖牛器膜経由て観䋈された EP（以下 EPI と略す）並 びに INPは哭䮖中大きな变動を示さず，EPIは+80mV 以上, INP はー70〜-90mVであった（図 2). 第 2 回 転の螖牛管側壁経由で観祭された EP（以下 EPII と略 す）実験中大きな变動学示さなかったが， $+65 \mathrm{mVW}$ 上と EPI に比校し低值であった（图 3 ）.

2) 遮宜実娩

遮血負荷後，45〜 50移以内比 $\mathrm{EP} は \mathrm{mV}$ となり，

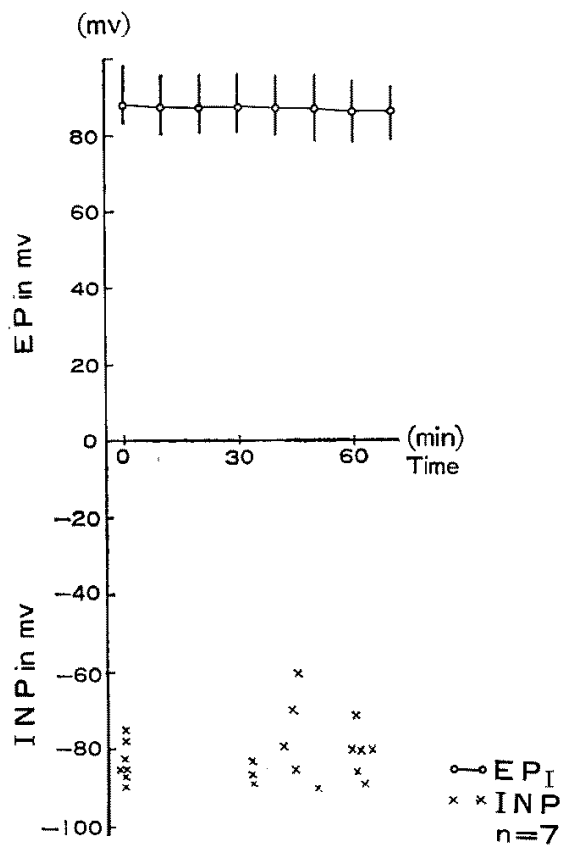

图 2 対照奏䮖（EPI）

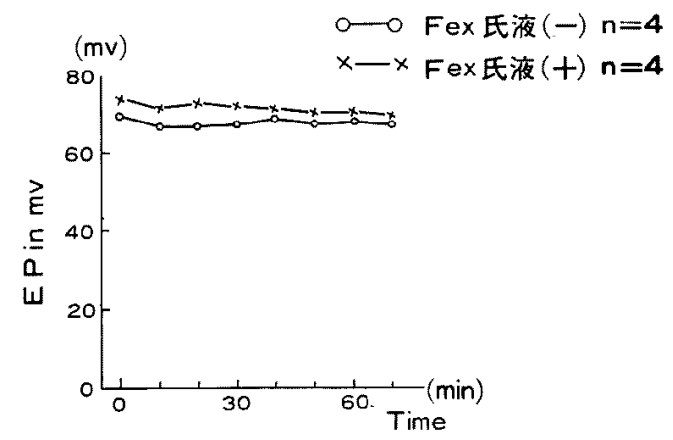

図 3 対照突験 $\left(\mathrm{EP}_{\mathrm{II}}\right)$

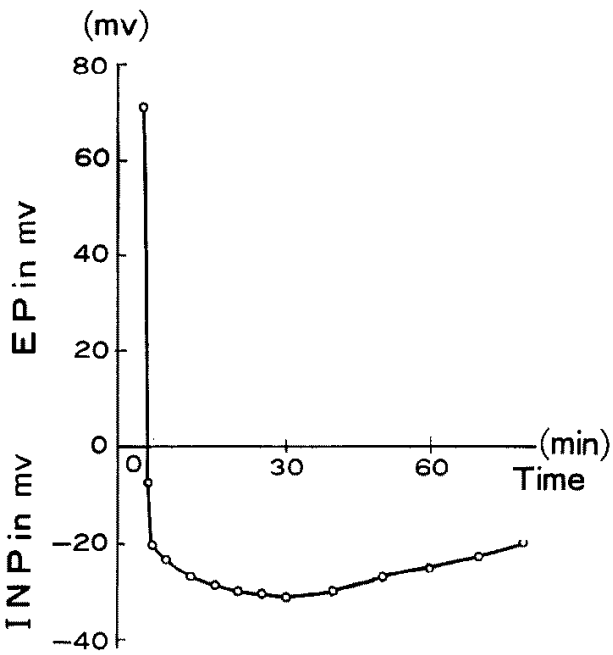

図 4 僬血実験 $\left(E P_{\text {II }}\right)$

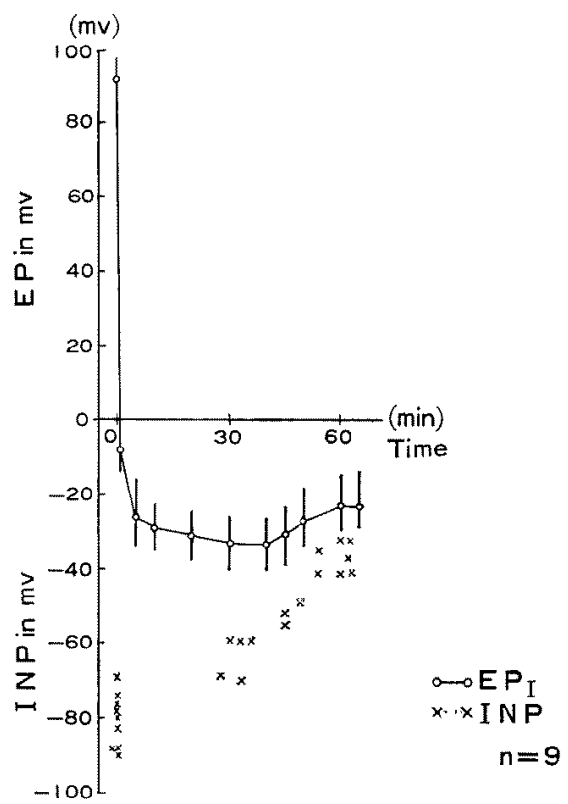

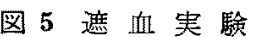

次いで極性を变じて負電位が生じた，負電位即らーEP

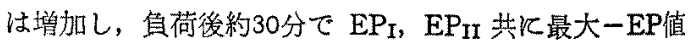
(EPI: $-34 \pm 6.4 \mathrm{mV}, \mathrm{n}=7, \mathrm{EP} I \mathrm{I}:-31 \pm 5.2 \mathrm{mV}$, $\mathrm{n}=9$ ）澾した. その後 EP は漸次減少, 消失して負 荷後60分で EPI，EPII はそれぞれー22士5.8mV となっ た（図 4，5）. INP は目荷的30分徭江消失し始め，艺の 
後はーEPIの消失過程にほ活類似したパターンで消失し た (図 5 ).

3）外りンパ灌流法火上る薬剂負何

\section{A，対照実験}

Fex 氏液単独負荷では $\mathrm{EP}_{\mathrm{I}} ， \mathrm{EP}_{\mathrm{II}}, \mathrm{INP}$ に大きな変 動証認められず，実験経過中，然負荷時の各電位（図2， 3）の大きさにほぼ等しかった（図 6), 即ち，EPI 泣+ $83 \mathrm{mV}$ 以上, EP II は+69mV 以上, INP は $-59 \mathrm{mV} \sim$ ー83mVであった。

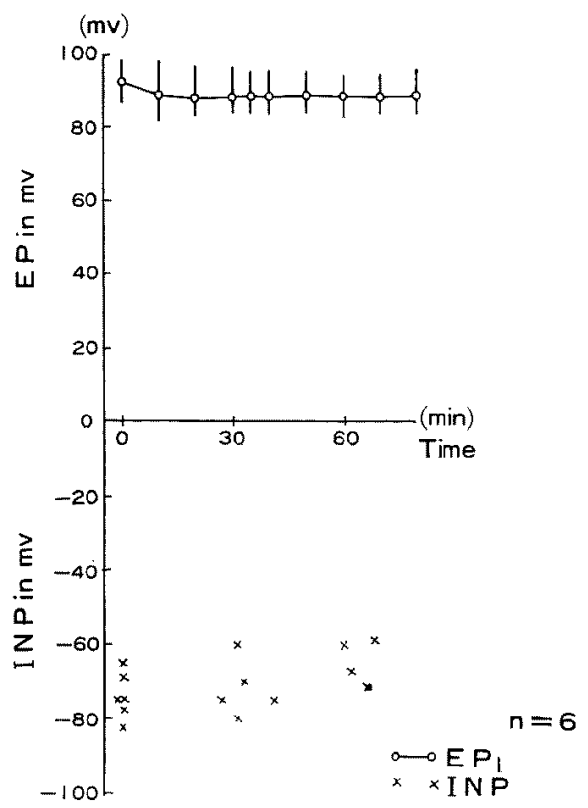

図 6 对照実験（Fex 氏液）

\section{B， MIAA 負荷実䮖}

1 0.1 mM 澧度の MIAA を負荷した。

a) $1 \mathrm{mM}$ 濃度真荷

$\mathrm{EP}$ は負荷開始後急速なる減少を呈し， $\mathrm{EP}_{\mathrm{I}}, \mathrm{EP}_{\mathrm{II}}$ 共V 負荷10分以内極性を転し，目荷20分後には最大減少値 $E P_{\mathrm{I}}:-42.8 \pm 5.7 \mathrm{mV}, \mathrm{n}=9, \mathrm{EP}_{\mathrm{II}}:-54.3 \pm 8.1 \mathrm{mV}$

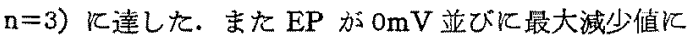

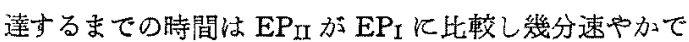
あった．その後の $\mathrm{EP}$ の変化は潮次減少消失し， $0 \mathrm{mV}$ 飞近づいた（図7，8）。INP は $\mathrm{EP}_{\mathrm{I}}$ が最大減少值飞達 する论怯々とんど変化せず，一EPI が減少を始めた時， ほほ同時儿隇少を始めた（図８）。

b) $0.5 \mathrm{mM}$ 濃度負荷

EP の減少嵮荷閒始後直ちれ起こり, 負荷20分以内

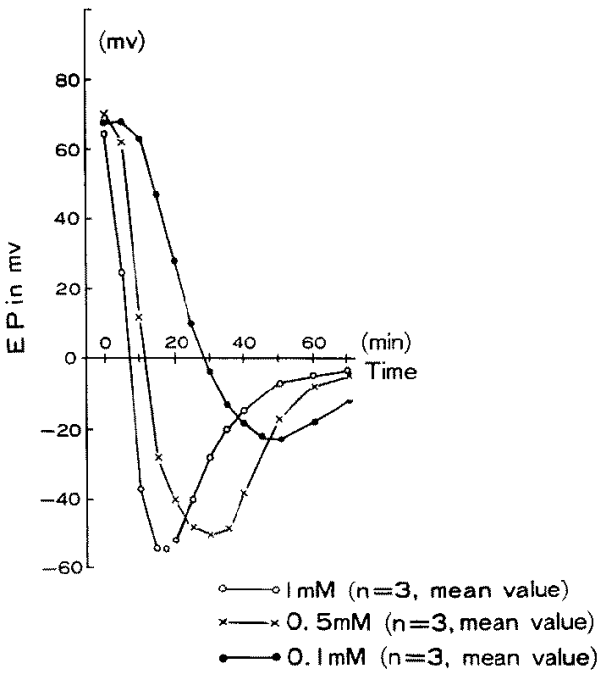

図 7 Monoiodoacetic acid (EPII)

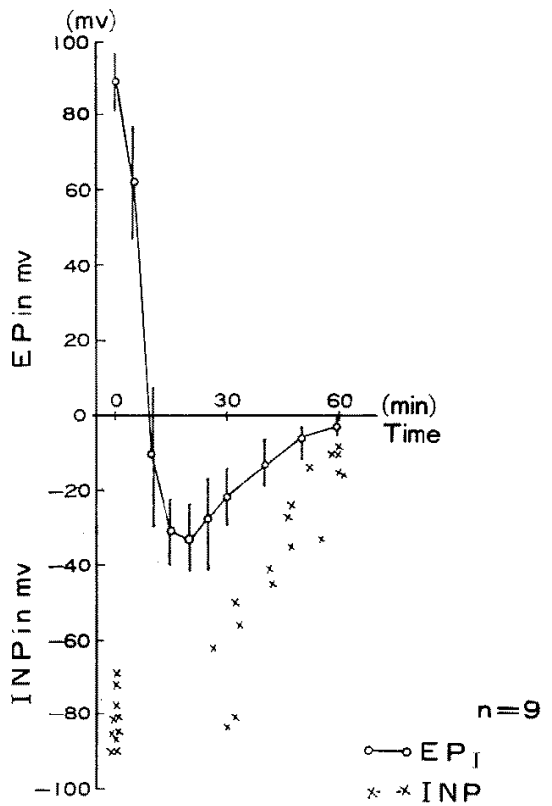

図 8 Monoiodoacetic acid $(1 \mathrm{mM})$

Ko $\mathrm{mV}$ 上なり, 負荷約 30 分後に最大娍少值 $\left(\mathrm{EP}_{\mathrm{I}}:-29\right.$ $\pm 6.6 \mathrm{mV} \mathrm{n}=9, \mathrm{EPII}:-48.5 \pm 2.1 \mathrm{mV} \mathrm{n}=3) k$ 造 $\mathrm{L}$, 次いでーEP の減少をきたした（図7，9）. INP はーEP の減少とほほ同時汇減少をきたし負荷60分後での大きさ は負荷前 $(-75 \sim-90 \mathrm{mV})$ K此較し，約50\% (-35 -55mV) 飞減少した（図9）。 


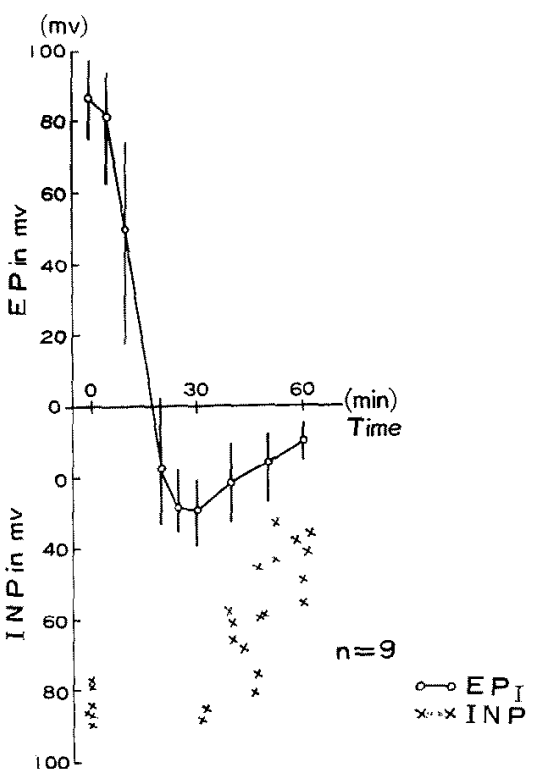

图 9 Monoiodoacetic acid (0.5mM)

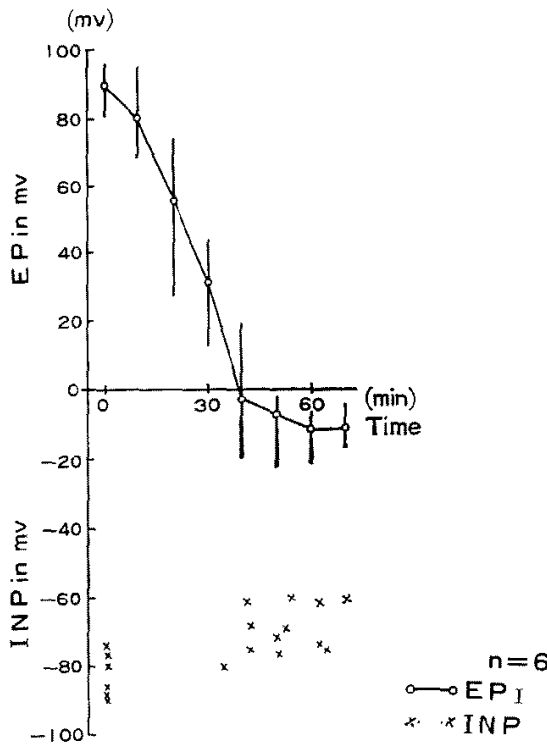

図 10 Monoiodoacetic acid (0.1 mM)

c) $0.1 \mathrm{mM}$ 濃度臽荷

$\mathrm{EP}$ の堿少は緩除となり, $\mathrm{EP}_{\mathrm{I}}$ は負荷約 40 分後に, EPII は負荷約30分でそれぞれ0 $\mathrm{mV}$ 上なったＥPI 負荷約60分で, EPI は真荷約 50 分後にそれ㢳れ最大減 少值 $\left(\mathrm{EP}_{\mathrm{I}} \mathrm{x}-10.1 \pm 7.0 \mathrm{mV} \mathrm{n}=6, \mathrm{EP}_{\mathrm{II}}:-22.7 \pm 7.1\right.$
$\mathrm{mVn}=3$ ) K達した。一EP の減少も緩除となった（図 7，10），INP の変化はほとえどなく，対照実験の結果 (図6) と類似の変動を示した（図10).

C, MA 負荷実駼

$1 \sim 0.1 \mathrm{mM}$ 灌度の MA を真荷した.

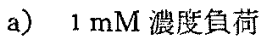

員荷開始直後化 EP は急激なる，一過性の增大を示 した，真荷 5 分徭儿鼠大堌大值 $\left(\mathrm{EP}_{\mathrm{I}}\right.$ ：平均 $+10 \mathrm{mV}$ 上 昇， $\mathrm{EP}_{I I}$ ：平均 $+17 \mathrm{mV}$ 上暑）火達し，次いで急速に減 少した。しかしな咕ら，EP は極性を逆棕してーEP K 等る重はなか力た（図11，12）．INP の変動は EP の增

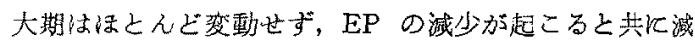

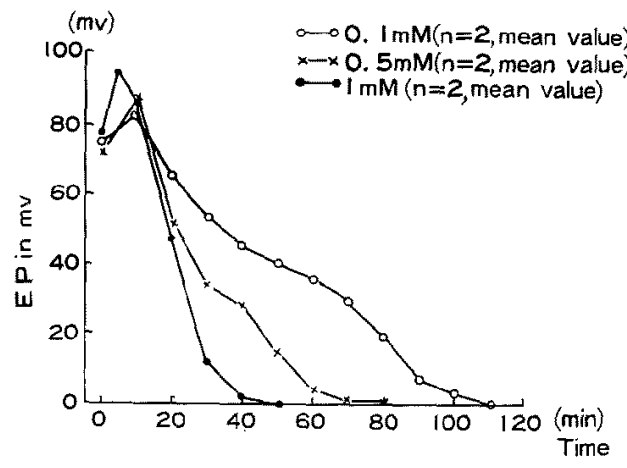

图 11 Mersalyl acid (EPII)

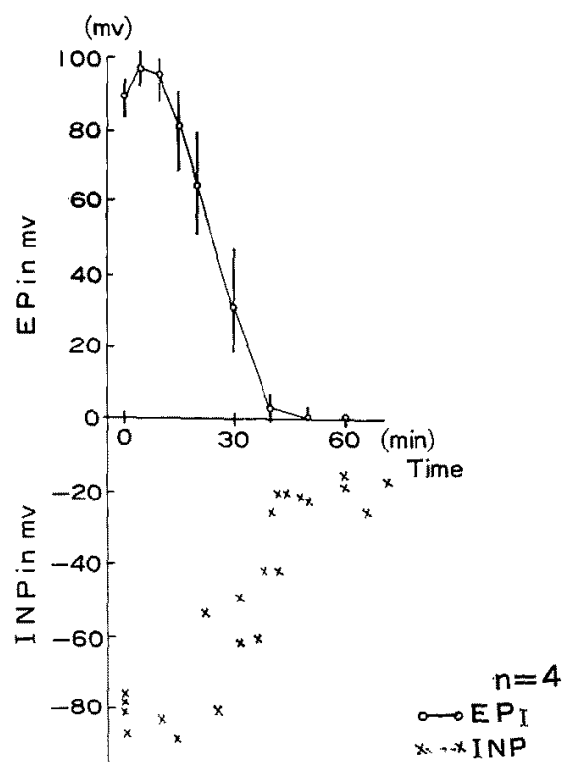

图 12 Mersalyl acid ( $1 \mathrm{mM}$ ) 
少を始めた。し加し，EP 值は負荷前の約 $25 \%$ (-15 -25mV) であった（园12）。

\section{b) $0.5 \mathrm{mM}$ 婊度負荷}

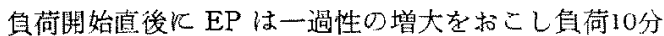
後飞最大增大值（EPI：平均 $+11 \mathrm{mV}$ 上㫧， $E P_{I I}$ ：平均 $+15 \mathrm{mV}$ 上显）飞達した。 その後 EP は渐次減少し $\mathrm{EPI}$ 崸荷 100 分, $\mathrm{EP}_{\mathrm{II}}$ 蛙荷 80 分後にそれぞれ $0 \mathrm{mV}$ と

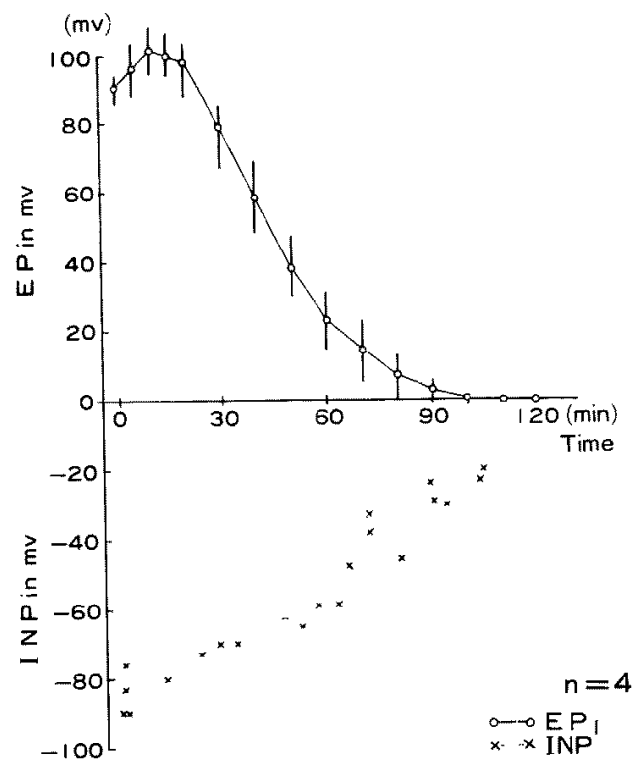

図 13 Mersalyl acid (0.5mM)

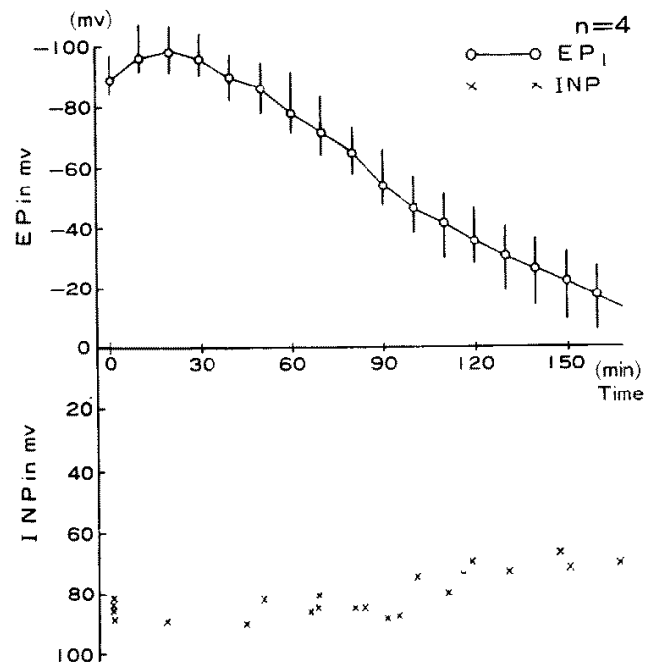

图 14 Mersalyl acid (0.1 mM)
なった，しかしながら，EP 虫椣性を变え一EP 亿逆転 しなかった（図11，13）. INP の变動はEP の增大期に ははとんど認められないか，EP の減少の開始上共に娍 少を示し具荷 105 分での INP 值は目荷前の INP 值の 約25\% (-20mV) であった（図13).

c) $0.1 \mathrm{mM}$ 濃度出荷

目荷 10〜20分で最大增大值（EPI，EPII 其に平均十

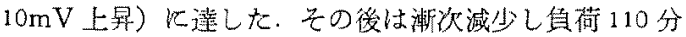
後の $\mathrm{EP}_{\mathrm{I}}$ は+40 $\mathrm{mV}, \mathrm{EP}_{\mathrm{II}}$ は $0 \mathrm{mV}$ となった（图11，

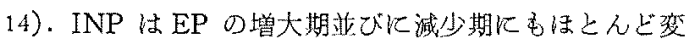
動しなかった（図14）。

D, p-HMB 真荷実娩

$1 \sim 0.1 \mathrm{mM}$ 浱度の p-HMB を真荷した。

a) $1 \mathrm{mM}$ 濃度角荷

EP は负荷同始得，速中加減少し，負荷 30 分後飞 EPII が，直荷35分後に EPI がそれぞれ $0 \mathrm{mV}$ となった (困16，17). INP 屯 EP の減少パターンとほほ同じパ ターンで城少し，EP が $0 \mathrm{mV}$ に達した真荷35 45分後 の INP 值はー2 - $5 \mathrm{mV}$ であった（図17）.

b) $0.1 \mathrm{mM}$ 裖度負荷

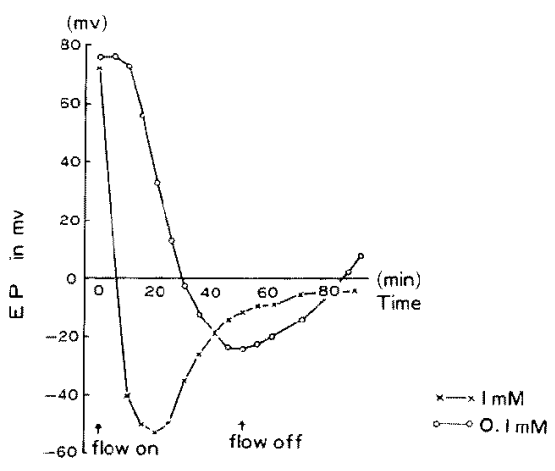

图 15 Monoiodoacetic acid (EPI)

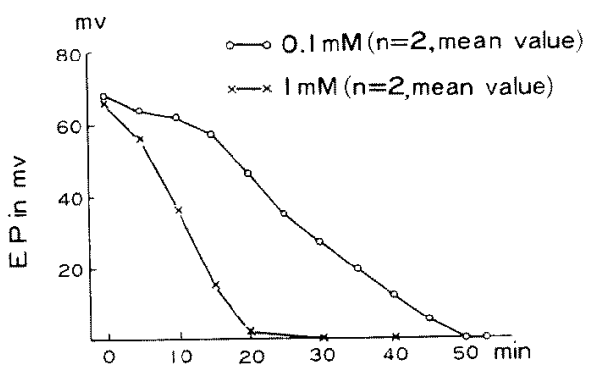

図 $16 \mathrm{P}-\mathrm{HMB}\left(\mathrm{EP}_{\mathrm{II}}\right)$ 


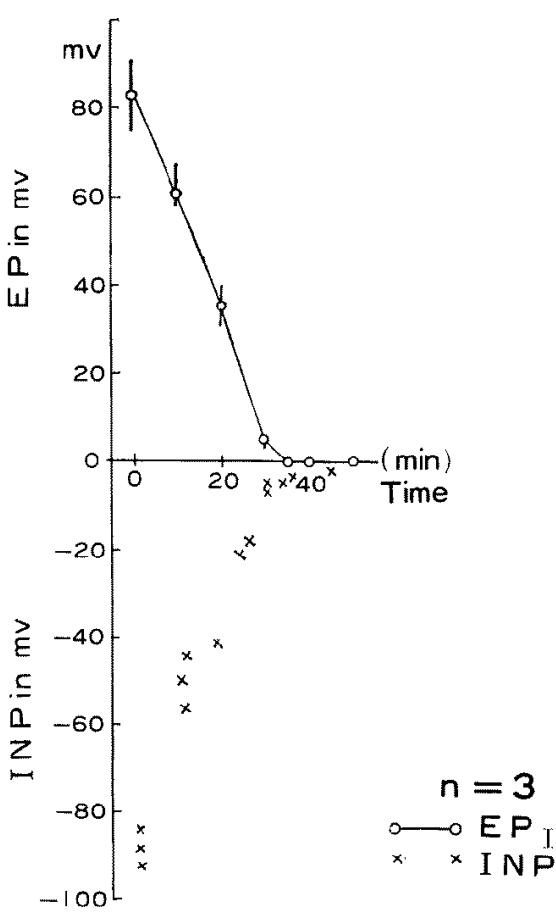

図 17 P-HMB ( $1 \mathrm{mM})$

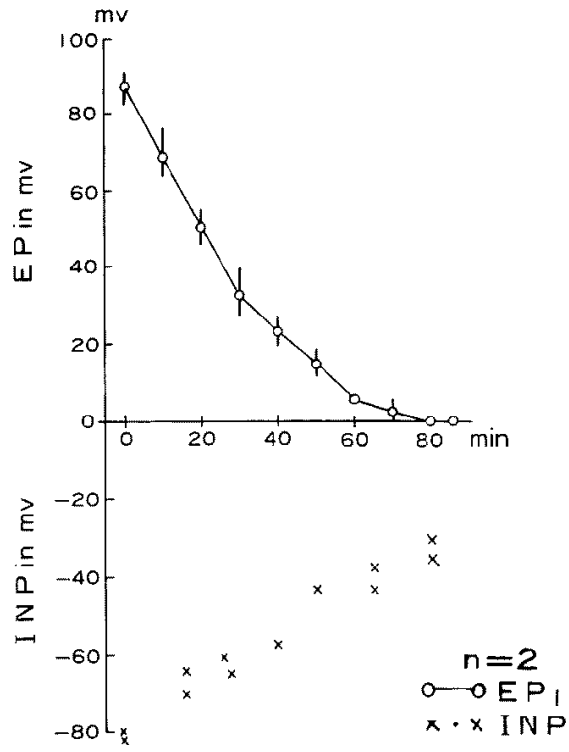

図 18 P-HMB (0.1 mM)

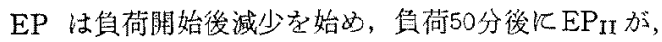
目荷80分㣪にEPIがそれぞれ0 $\mathrm{mV}$ 亿遠した。しかしな がら，1 $\mathrm{mM}$ 濃度負荷時と同様にーEP 示さなかった
(図16,18). INP は EP の減少バターンに比較しより

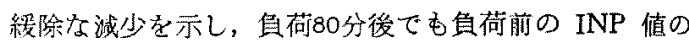
䄪 $40 \%(-30 \sim-35 \mathrm{mV})$ が残存し龙（因18).

\section{考按}

緒言で記载したごとく，EP 掂びに INP は1952 年 Bèkèsy ${ }^{1)}$ 飞よって発見された 眮牛内直流電位である。 これら再電位は近年, 内リンパのイオン組成維持任重要 な役割を演じ426)，更飞譓賞発生のための感覚有毛緗胞 の高感度維持にも関与していると示辂され，種々の型の

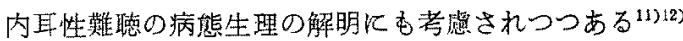
(3)14)16)。しかしなが，こらの雨電位一特にEP-の発 生機構並びに存在意義等について未解明な点加多い.

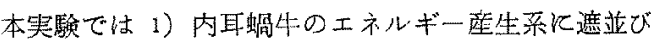
に糖代碓阻害剂鼻荷を与えた時，EPにどのような型の 变動様式を示すか！，2）上記目荷後に扢こる EP の变 動様式と INP の变勤様式との間に何らかの関連性が存 在する加否加？，以上 2 点火ついて検索し，EPの発生 機粠の解明を誈みた。

1) 蝸牛真流霓位 (EP)

EP は血管条で産生され，哭負荷状態では＋70 +90 $\mathrm{mV}$ の正の電位（+EP）である。しかしながら，遮血 負荷並びに MIAA 真荷で EP.は容吻に減少をきたし， 㥛性を変して員の䉓位となる。この現象は $\mathrm{EP} か ゙+\mathrm{EP}$ 上一E上から成り立っている事を示している.

血箩条に和ける榶代謝も他の組織の場合と同し人，第 一段階心嫝気的過程（ピルビン酸座生）で，好気的過程 (ピルビン酸利用) 加第二段階の反応系であると考兄ら れる.本实験飞初いても MIAA で煻代謝の第一段段階 を，遮血真荷で第二段階をそれぞれ阻害すると（図19）

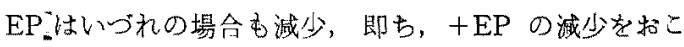
し上記の罗当性を示した。

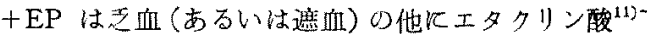

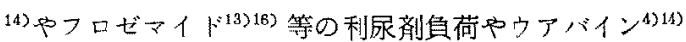
26)27の目荷でも容舄江減少する事が知られている。糖代

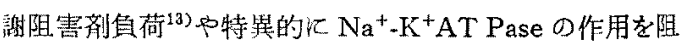
管するウアバイン等の負荷で容易に+EPが減少すると

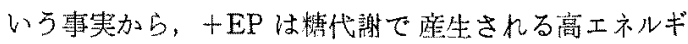
一源(ATP)利用した能動輸送（叔そらく $\mathrm{K}^{+}$electrogenic pump) Kよって生成されか26)，内リンパの特翼的 なイオン浱度 (高 $\mathrm{K}^{+}$，低 $\mathrm{Na}^{+}$) 維持に関与していると考 兑られる。

他厅, 内耳の血等条と留組織との組織学的類似性 ${ }^{28283}$ 


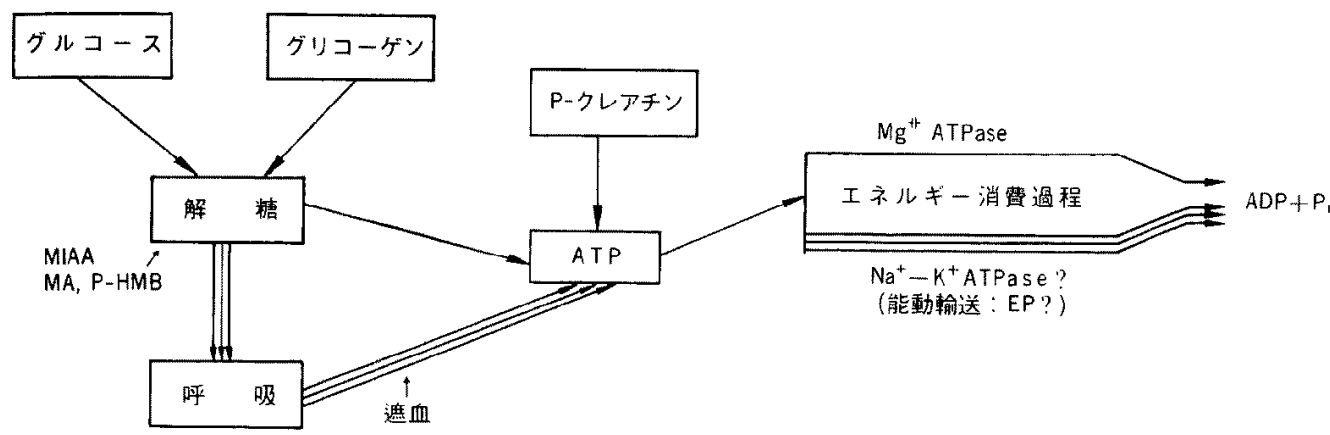

図 19 遮血，糖代铸阻害剂の作用機序:

から前記利尿郕は血管条飞対しても腎に対する上同様に $\mathrm{Na}^{+}$の再败收阻害剂 ${ }^{3031)}$ として作用し内リンパの $\mathrm{Na}^{+}$ 濃度を異常に増大さ地るという報告 ${ }^{16}$ あある。

MIAA 並びに遮血各真荷により，EP 活堿少し相性を 变して直ちにーEP となった。このーEP は酸素依存度 加低々，息血負荷後にも比較的長時間存在した，更にウ アバイン直荷後も比較的安定したーEPが出現する゙2门 事加ら，一EP の発生には大きなエネルギー源は不必要 と考允られる。一Eの発生部位は不明であるが，高 $\mathrm{K}^{+}$ 液を外リンパ中に灌流負荷し，外りンパのイオン濃度岛 配を除去すると，一EP はほぼ完全に消失する゙事から

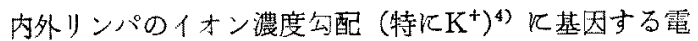
位であらうと考えられる。また，内外リンパのイオン濃 度勾配の維持には血管条のみでなく，内外りンを境する 膜様組織すべてが関与しているのであるう。

MIAA 負荷並ひ儿遮血负荷で出現したーEP は次第 に隇少をきたした。これは2つの型の隇少堂意味すると

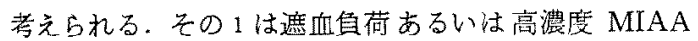
賲荷時にみられるーEPの減少で，血篦条の内リンパイ オン濃度の維持機構の阻害並びにラセン器構成細胞を含 む内外りンパ腔を境する細胞群の膜の透過性の崩壊の結 果，内外リンパのイオン濃度勾配方失なわれるために起

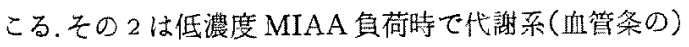
が部分的飞阻害を受けた時, エタタリン酸们ややフロゼ マイド(3)15)各真荷でみられるように EP の回復で - EP が隇少するためてこの場合には内外リンパのイオン濃度 勾配には著変がなく，+EP の回復が進むにつれて -

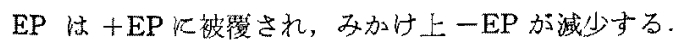
これより真の一EPの隇少とは前者子指し, 淩者の变化 は隇少とは言元めと思われる(図 15).

2) 螖牛鲁流電位とラセン器直電位との関連性.
INP はラセン器内の緭胞間腔（トンネル，Nuel 腔）

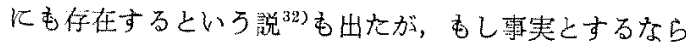
ば，これら間腔学通り有毛紨胞（感賞細胞）に分布して

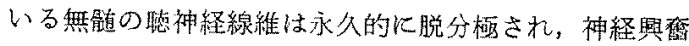
は括こり得ず，踾覚は発生しなくなる事から，現在では ラセン器を棈成している細胞内の䉓位であるうと考えら れるようになった．後藤 ${ }^{17}$ は細胞マーキング用の色素安 電極に充填し，INP の記録後直ちに霓極を記録系加ら 通気系飞切り换无て色素を細胞内に泳動さ世，組織学的 に電極刺入細胞を分類した結果，ラセン器負電位の大き さは外有毛細胞では約 $-70 \mathrm{mV}$, 内有毛細胞で約ー60〜 $-80 \mathrm{mV}$ ，支持細胞では約－80〜ー90 $\mathrm{mV}$ であった。低 濃度 MIAA 負荷特の EP の变化は前記のごとくである が, EP がたとえーEP まで減少しても INP は不変て あった.フロゼマイド筫荷並びにェタクリン酸苗渮であ EP の減少，INP の不变という赫果 ${ }^{8}$ 老得ている。この

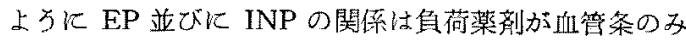
の代謝機能を阻害しラセン器には大きな影響を及はさ好 ためとも考无られる、エ夕クリン酸と異なり、ラセン器を

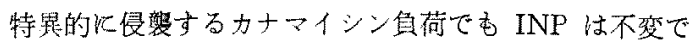

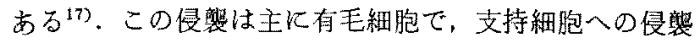
はかなり遅れるためと考えられる。しかし，支持細胞へ

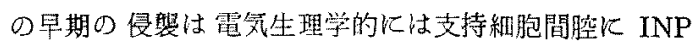

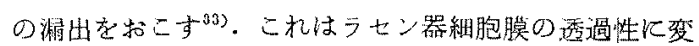

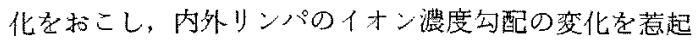

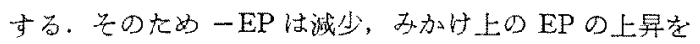

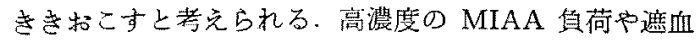

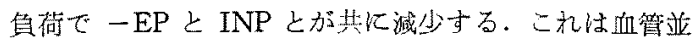
びにラセン器細胞の糖代謝阻賣によるもので，同時に内 外リンパのイオン浱度勾配の变化でーEPの減少加おこ ると考党られる。 
次火 MA 並びに p-HMBを真尌すると, 従来の報告 K晃られ双 $\mathrm{EP}$ 並びて INP の变化があこった。高溜度

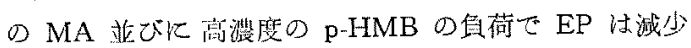

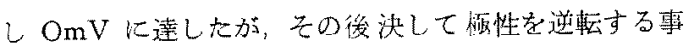
はなかった，これは一EPの消失が +EPの消失と同時

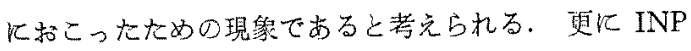
も $\mathrm{EP}$ の減少と括初上そ比例して減少した。このような

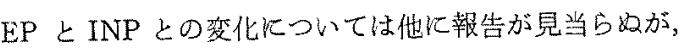
これら薬郕は血管条とラセン器化対して同程度の代謝阻 害を与えるため江内外りンパのイオン濃度の变化屯速や 加标こり，+EP のみならず - EP 並びK INP の娍 少が同昲炕こると考えられる.

しかしながら低濃度の MA 並びに p-HMB 負荷に対 しては血管条に比較しラセン器への代謝阻害効果が弱い ため飞 INP の減少は僅かとなる，EP の減少は +EP と同時飞一EPの減少がみられ，依然として内外リンパ のイオン漲度勾配化大きな变化をきたすと考光られる。

EP 並びK INP に対する MA の作用は p-HMB の

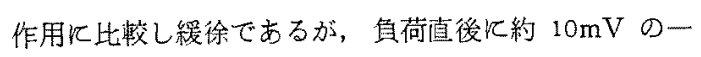

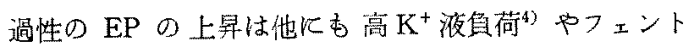

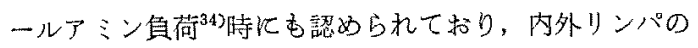
イ九ン䟴度刨配が急激に变化し，一EP が娍少するため に+EP がみかけ上增大するすのと考无られている、し

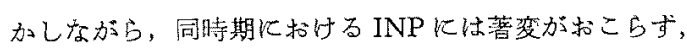
カナマイシン負荷時炕括こると思和れる内耳への反灾と 同様の反応が急激化括こるためと考光台れる。

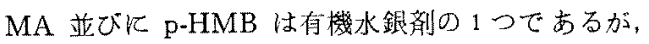
MIAA と同じく生体内組織で糖代謝解搪系の阻害剂|23) 35336637)として作用するが，特にこれら有機水銀骩は他の

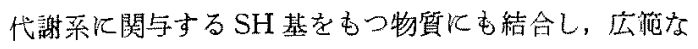
る代䇋阻害をひき招こす事も考えられる。

MA 並び氏 p-HMB 負荷に上る蛤牛内直流電位への 効果以特買な变化を示す事が明らかにされたが，これら

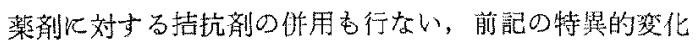
が可逆性恋化であるか否かを㭘索し，更沃 EP の発生機 辢の解明に努力したい。

\section{総 括}

1）上行大動脈切断後の内耳の遮血状態で $+\mathrm{EP} は$ 速や かに消失し，その後出現する-EPは20〜30分間不变の ままとどまるが次いで減少消失したＩNPの減少消失は 一EP の減少消失上ほぼ同時飞㧍こった。

2） MIAA 筫荷並びに有機水跟剂負荷後, 容易に+EP
は消失した。しかし，一EP の減少消失様式は MIAA 真荷と有機水銀剂鱼荷上の場合で異なり MIAA 負荷時 飞はか惊り大きなーEP の出現を呈したにあかかわらず 有機水銀負荷時には - EP O出現は全く認められなかっ た. これは有機水銀剂 (MA 並びに p-HMB) 負荷で, $+\mathrm{EP},-\mathrm{EP}$ 並び飞 INP がほほ同時伹害作用を受け る事を示唆している，MIAA 負荷時のINP の隇少消

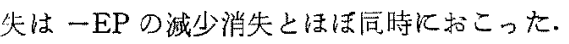

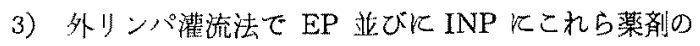
影響を及ほす事が可能である事から外リンバはう七ン器 細胞のみならず血管条との閒化す交通路が存在する事を 示唆している.

4)内耳の結代謝一嫌気並び汉好気的過程一を阻害した 結果, +EP は非常飞速やか炕減少消失したが，一EP 並びに INPはかなり遅延性に減少消失した。これは十 EP は喨代謝で産生される高エホルギー源化依存性が強 い事を示唆し, INP の発生には ネルギーが必要でないと思われるＩNP の隇少消失は ラセン器細胞の膜透過性の異常を招き, 強いては内外り ンパのイオン組成維持を不可能とし，-EP の減少消失 を括こ声と考穴られた。

\section{参文 献}

1) Bekèsy $G V:$ DC resting potentials inside the cochlear partition J. Acoust. Soc. Am. 24: 7276, 1952.

2) Davis $H$ : Biophysics and physiology of the inner ear Physiol. Rev. 37: 1-49, 1957.

3) Tasaki I, Spyropoulous C S: Stria vascularis as source of endocochlear potential J. Neurophysiol. 22: 149-155, 1959.

4) Kuijpers $W$ : Cation transport and cochlear function Thesis. University of Nigmegen 1969.

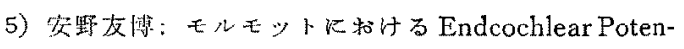

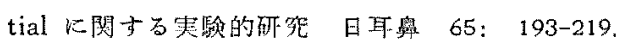
1962.

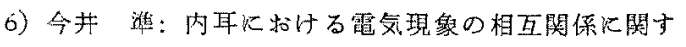
万実験的研究 日耳鬼 $71: 100-123,1968$.

7) Davis H: Mechanism of the inner ear Ann. Otol. 77: 644-655, 1968.

8）田中康夫等：ラセン器の直流電位と $\mathrm{CM}$ との分布 Audiology (Japan) 18: 241-245, 1975.

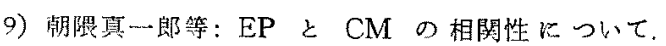


Audiology (Japan) 18: 246-254, 1975.

10) Smith $C$, et al.: The electrolytss of the labyrinthine fluids Laryngoscope 64: 141-153, 1954.

11) Kusakari $J$ : Effect of ethacrynic acid, furosemide and ouabain upon the endolymphatic potential and stria vascularis upon high energy phosphates of the stria vascularis Laryngoscope 88: $12-37,1978$.

12) Bosher $S K$, et al:: The effect of Ethacrynic acid upon the cochlear endolymph and stria vascularis Acta. Otolaryng (Stockh) 75: 184191, 1973.

13) Thalmann $R$, et al.: Normal and abnormal energy metabolism of the inner ear. The Otolaryngologic clinics of North America 8: 313$333,1975$.

14) Sellick $P M$ aad Iohnstone $B M$ : Differential effects of oubain and ethacrynic acid on the labyrinthine potentials Phlugers Arch. 352: 339$350,1974$.

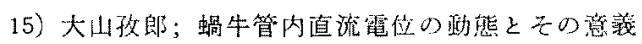
Audiology (Japan) 18: 255-260, 1975.

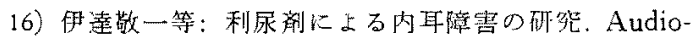
logy (Japan) 14: 429-430, 1971.

17) 後藤 健：各镣条件下に和けるコルチ器細胞内鱼電

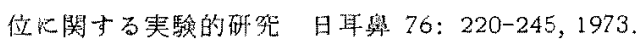

18) Jakob $A$ and Diem $S$ : Activation of glycogenolysis in perfused rat livers by glucagon and metabolic inhibitors Biochemica et Biophysica Acta 362: 469-476, 1974.

19) Hays $F D$, et al. Differential toxicity of Monochloroacetate, Monoluoroacetate and Monoiodoacetic acid in rat Toxicology and Applied Pharmacology 26: 93-102, 1973.

20) Beigelman $P M$ and Thomas $J r . L J$ : Liver cell potentials; In vitro effects of metabolic inhibitors cardiac glycosides and hormones $\mathrm{J}$. Menbrane Biol. 8: 181-188, 1972.

21) Ponte F, et al.: Iodoacetic acid influence of the aerobic glycolosis in surviving retinae of normal rat and of inherited retinal degeneration Ophthalmologica 168: 475-480, 1974.

22) Nakazawa $N$, et al.: Acute effects of Mercuric compounds on cultured mammalian cells Biochemical Pharmacology 24: 489-493, 1975.

23) Fox $J H$, et al.: Comparative effects of organic and inorganic mercury on brain slice respiration and metabolism J. Neurochemistry 24: 757-762 1957.

24) 伊藤 宏: 藻理学「利尿蒋」䓋文堂 292-310, 1966.

25) Schnieder E A: A contribution to the physiology of the perilymph Part 1; The origins of perilymph Ann. Otol. 83: 76-83, 1974.

26) Kuijpers $W$ and Bonting $S L$ : Localization and properties of ATPase in the inner ear of the guinea pig Biochem. Biophys. Acta. 173: 477$485,1969$.

27) Konishi $T$ and Mendelsohn $M$ : Effect of ouabain on cochlear potentials and endolymph composition in guinea pig Acta Otolaryngol (Stockh) 69: 192-199, 1970.

28) Quick $C A$, et al.: The relationship between cochea and kidney Laryngoscope 83: 1469-1482. 1973.

29) Johnson $D W$ and Mathog $R H$ : Hearing function and chronic renal failure Ann. Otol. 85: 43-49, 1976.

30) Goth A: Diuretic Drugs Medical Pharmacology 7th edition The C.V. Mosby Company St. Louis 423-440, 1974.

31) Goodman $L S$ and Gilman A: Diuretics and other agents employed in the mobilization of edema fluid The Pharmacological Basis of Therapeutics 4 th edition The Macmillan company Lond. 817-847, 1970.

32) Butler $R A$, et al. Cochlear function under metabolic impairment Ann. Otol. 71: 648-656, 1962.

33）中島恒培，山本哲生：カナマイシソ骤モルモットの

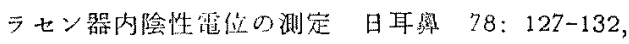
1975.

34) Ahlstrom P, et al.: Cyclic AMP adenylate cyclase in the inner ear Laryngoscope 85: $1241-$ $1257,1957$.

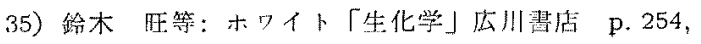
$350,465,468,1970$. 
36) Southard $J H$ and Green $D E$ : Control of the energy coupling modes in mitochondria by mercurials Biochem. Biophys. Res. Commun. 61: 1310-1316, 1974 .

37) Gage $J C$ : Mechanism for the biodegradation. of organic mercury compounds; The action of ascorbate and of souble proteins Toxicology and Applied Pharmacology 32: 225-238, 1975.
稿を終るにあたり，御指涪，御校閱いただいた河本和

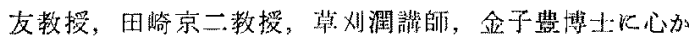
ら感謝致しす。

（原搞受付 䧂和53，11，8日）

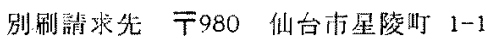

東北大学医学部耳婎咽搌科学教室 护繁 郁夫 